\title{
Presence of Salmonella in retail grade a eggs determined by the International Organization for Standardization 6579 method and a LightCycler polymerase chain reaction system
}

\author{
Seran TEMELLi' ${ }^{1}$, Serpil KAHYA ${ }^{2}$, Zafer ATA ${ }^{1,3}$, Kamil Tayfun CARLI $^{2}$, Aysegul EYIGOR ${ }^{1}$ \\ Uludag University Faculty of Veterinary Medicine, ${ }^{1}$ Department of Food Hygiene and Technology, ${ }^{2}$ Department of Microbiology, \\ Bursa,; ${ }^{3}$ Military Veterinary School and Educational Central Commandership, Gemlik, Bursa, Turkey.
}

\begin{abstract}
Summary: This study aims to determine the presence of Salmonella in naturally contaminated grade A eggs by the standard culture method International Organization for Standardization Method 6579 (ISO) and a specific real-time PCR system (LightCycler PCR-LCPCR) to complement ISO. A total of 1635 eggs pooled into 101 samples were randomly collected within one year period from 20 different retail markets in Bursa, Turkey, carrying eggs of 16 large egg producers/suppliers of 5 cities with intensive layer production. Preparation of the egg and shell for analyses, Salmonella isolations and identifications, and detections were performed according to ISO 6887-4:2003, ISO 6579 and LCPCR, respectively. Overall Salmonella detection rate by ISO and LCPCR were 15.8 $\%(16 / 101)$ and $46.5 \%$ (47/101), respectively. Out of 101 inner parts, Salmonella was detected in 11 (10.9\%) samples by ISO, and in $31(30.7 \%)$ samples by LCPCR. Six of 101 shell samples $(5.9 \%)$ were found to harbor Salmonella by ISO, while 18 (17.8\%) shells were positive by LCPCR. All isolates were determined as Salmonella enterica subsp. enterica serovar Enteritidis. These findings indicate considerably high Salmonella contamination in retail grade A eggs. This should be under routine monitoring by rapid methods such as PCR, complemented by standard culture to evaluate and assess the significance of risk for public health.

Key words: ISO 6579, real-time polymerase chain reaction, retail egg, Salmonella.
\end{abstract}

\section{Perakende A sınıfı yumurtalarda Salmonella varlığının ISO 6579 metodu ve LightCycler polimeraz zincir reaksiyonu ile belirlenmesi}

Özet: Bu çalışmada doğal kontamine A sınıfı yumurtalarda Salmonella varlığının ISO 6579 standart kültür metodu ve bu metodun spesifik gerçek zamanlı bir PCR sistemi (LightCycler PCR-LCPCR) ile desteklenmesini belirlemek amaçlanmıştır. Bursa'da 20 farklı perakende marketten 1 yıl süresince, yoğun yumurta üretimi olan 3 bölge (Ege, Marmara, Orta Anadolu)'nin büyük üretici/tedarikçisi olan 16 farklı firmaya ait 101 birleştirilmiş, toplam 1635 adet yumurta rastgele olarak örneklendi. Yumurtaların analize hazırlanması, Salmonella izolasyonu ile identifikasyonu ve deteksiyonu sirasiyla ISO 6887-4:2003, ISO 6579'a göre ve LCPCR ile yapıldı. Yumurtalarda genel Salmonella deteksiyon oranları ISO ve LCPCR ile sırası ile \%15.8 (16/101) ve \% 46.5 (47/101) olarak belirlendi. Yüzbir iç örneğinin ISO ile 11'inde (\% 10.9), LCPCR ile 31'inde (\% 30.7) Salmonella saptandı. Kabuk örneklerinden 6'sında (\% 5.9) ISO ile Salmonella bulunurken, 18'i (17.8 \%) LCPCR ile pozitif olarak tespit edildi. Tüm izolatların Salmonella enterica subsp. enterica serovar Enteritidis olduğu belirlendi. Bu bulgular perakende A sinıfi yumurtalarda Salmonella kontaminasyonunun oldukça yüksek olduğunu ve bu durumun halk sağlığı açısından önemini belirlemek ve değerlendirebilmek için standart kültür metodu ile desteklenen PCR gibi hızlı bir metotla rutin olarak izlenmesi gerektiğini göstermektedir.

Anahtar sözcükler: ISO 6579, gerçek zamanlı polimeraz zincir reaksiyonu, perakende yumurta, Salmonella.

\section{Introduction}

Salmonella is known as the most important cause of foodborne bacterial enteritis in many countries. Besides the high morbidity and mortality rates in food-borne salmonellosis, food recalls and withdrawals are known to cause significant economical losses in the food industry (22). European baseline studies of 2005-2006 reports Salmonella spp. infection rate in European Union as $30.7 \%$ in layers (6). The most important sources in Salmonella infections and outbreaks are contaminated poultry meat, egg and egg products (25). Many studies performed in different countries and in our country indicate that egg and egg products were contaminated with Salmonella in various rates $(1,19)$, and lead to Salmonella-related outbreaks (23).

Rapid detection of Salmonella in eggs and its products are of great significance in preventing foodborne salmonellosis. However, Gold Standard culture methods (e.g. International Organization for Standardization Method 6579 [ISO], United States Food and Drug 
Administration's Bacteriological Analytical Manual Chapter 5: Salmonella), which require up to 5 days (including biochemical and serological confirmations) $(11,15)$, do not suffice in routine and rapid monitoring of these samples. In recent years, novel real-time PCR assays were developed for the rapid detection of Salmonella particularly from eggs (5). LightCycler PCR (LCPCR) is a specific real-time PCR system enabling rapid and reliable detection of the specific PCR product with probe-based technology and high sensitivity (3). Still, complementation of PCR by standard culture is required for the elimination of possible false negative and/or variable PCR results related to inhibitory substances within the process (29), and for avoiding false positive results due to amplification of target DNA from dead/non-culturable/injured Salmonella cells in the sample (20).

We conducted this study to determine the presence of Salmonella and its possible risk on public health in retail grade A eggs in Bursa, which were produced mainly in 5 cities (Balıkesir, Bursa, Manisa, Sakarya, Ankara) in Turkey by the 'internationally-recognized' standard culture method ISO 6579 (ISO) and a rapid specific real-time PCR system (LightCycler PCRLCPCR) to complement ISO in detecting Salmonella from naturally contaminated eggs.

\section{Materials and Methods}

Salmonella strains: SE 64K (M.Y. Popoff, Institut Pasteur, 28 rue du Dr Roux, 75015 Paris Cedex 15, France), and Salmonella enterica subsp. enterica serovar Typhimurium NCTC 12416 (Refik Saydam National Public Health Agency, Ankara, Turkey) were used as positive controls in ISO and LCPCR tests.

Sampling strategy in collection and analysis of egg samples: A total of 1635 eggs were collected and were pooled into 101 samples ( 1 sample $\geq 12 \mathrm{egg} / \mathrm{viol}$ ) were randomly collected from 20 different retail markets in Bursa, which carry eggs of 16 large egg producers/ suppliers of 5 cities with intensive layer production, within one-year period (Table 1). Analysis of all samples was initiated immediately after transfer to the laboratory.

Culture: Two groups of randomly selected-6 eggs from each sample group were used for the culture of Salmonella from inner part and shell of the egg. Eggs used for culture from inner part were handled by using sterile gloves and prepared by the method described in ISO 6887-4:2003, Chapter 9.6.1.2 (16) for analysis. Isolation and identifications were performed as indicated in ISO 6579 (15). Serotyping was performed on the basis of reaction with $\mathrm{O}$ - and $\mathrm{H}$-group antigen, according to the White- Kauffmann-Le Minor Scheme (13) and in Guibourdenche et al. (14) by using commercial antisera (Becton Dickinson). Eggs to be used for culture from shell were handled by using sterile gloves and prepared by the 'Soaking method' described in ISO 6887-4:2003, Chapter 9.6.2.4. (16). Isolation and identifications were performed as indicated above in the culture from inner part.

DNA isolation and LCPCR: DNA from $1 \mathrm{ml}$ aliquot taken from the primary enrichment step of ISO 6579 (15) for each shell and inner part egg sample was isolated by using Foodproof Sample Preparation Kit I (Biotecon, 1.20473.0001, Germany). Isolated DNA was used as template in LCPCR (LightCycler 2.0 Instrument, Roche, 03531414201, Germany), which was performed by using a Foodproof Salmonella Detection Kit (Biotecon, 1.20453.0001, Germany) after concentration and purity determination by NanoDrop Spectrophotometer (Thermo, ND1000, USA). The total PCR reaction volume was 20 $\mu \mathrm{l}$ comprised of $5 \mu \mathrm{l}$ of template DNA added into $15 \mu \mathrm{l}$ PCR mix (13 $\mu$ l of Foodproof Salmonella Master Mix [ready-to-use primer and hybridization probe mix], $1 \mu 1$ of Foodproof Salmonella Enzyme Solution [FastStart Taq DNA Polymerase and Uracil-DNA Glycosylase, heat labile, for prevention of carry-over contamination], $1 \mu \mathrm{l}$ of Foodproof Salmonella Internal Control. The Foodproof Salmonella Control template DNA, and DNA from one of the selected Salmonella strains indicated above were used as positive controls; and PCR-grade water was used as a negative control in PCR. The amplification protocol and data analysis was performed as indicated in the kit insert and by the LightCycler software version 4.1, respectively.

Statistical analysis: Relative accuracy, sensitivity, and specificity were calculated according to the protocol described in ISO 16140 (17). Relative accuracy, sensitivity, and specificity calculations were complemented with Cohen's kappa test to evaluate the correspondence between results obtained by methods.

\section{Results}

In this study, the overall Salmonella detection rate by ISO and LCPCR are $15.8 \%$ (16 out of 101 samples) and $46.5 \%$ (47 out of 101 samples), respectively. Out of 101 inner parts, Salmonella was recovered in 11 (10.9\%) samples by ISO, compared to $31(30.7 \%)$ inner part positive samples by LCPCR. Six of the 101 shell samples (5.9\%) were found to harbor Salmonella by ISO, while $18(17.8 \%$ ) shells were positive by LCPCR (Table 1).

A total of 10 samples comprised of 6 inner (sample no $78,80,83,85,96,97$ ) and 4 shell (sample no 12,82 , $88,93)$ parts were found Salmonella positive both by ISO and by LCPCR. There were 6 samples (sample no $73,86,89,92,94,95)$ detected only by ISO, and 37 samples detected only by LCPCR. One sample (sample no 92) and 2 samples (sample no 4 and 97) were positive for Salmonella by ISO, and by LCPCR both in their inner and shell parts (Table 1). 
Table 1. Summary of egg sampling strategy and results of culture (ISO) and LCPCR. Tablo 1.Yumurta örnekleme stratejisi özeti ile kültür (ISO) ve LCPCR sonuçları.

\begin{tabular}{|c|c|c|c|c|c|c|c|c|c|}
\hline \multicolumn{6}{|c|}{ Sampling strategy } & \multicolumn{4}{|c|}{ Results } \\
\hline \multirow{2}{*}{$\begin{array}{l}\text { Sampling } \\
\text { period }\end{array}$} & \multirow{2}{*}{$\begin{array}{c}\text { No of } \\
\text { samples }\end{array}$} & \multirow{2}{*}{ City } & \multirow{2}{*}{ Supplier } & \multirow{2}{*}{ Retailer } & \multirow{2}{*}{$\begin{array}{l}\text { No: eggs } \\
\text { sampled }\end{array}$} & \multicolumn{2}{|c|}{ Inner positive sample ID } & \multicolumn{2}{|c|}{ Shell positive sample ID } \\
\hline & & & & & & ISO & LCPCR & ISO & LCPCR \\
\hline \multirow[t]{8}{*}{ Jun11 } & 1 & Bursa & A & a & 15 & - & - & - & - \\
\hline & 2 & Bursa & $\mathrm{A}$ & a & 15 & - & - & - & - \\
\hline & 3 & Bursa & A & a & 15 & - & - & - & - \\
\hline & 4 & Sakarya & $\mathrm{B}$ & $\mathrm{b}$ & 10 & - & 4 & - & 4 \\
\hline & 5 & Sakarya & $\mathrm{B}$ & $\mathrm{b}$ & 10 & - & - & - & - \\
\hline & 6 & Manisa & $\mathrm{C}$ & $\mathrm{c}$ & 10 & - & - & - & - \\
\hline & 7 & Manisa & $\mathrm{C}$ & $\mathrm{c}$ & 12 & - & - & - & - \\
\hline & 8 & Manisa & $\mathrm{C}$ & $\mathrm{c}$ & 12 & - & - & - & - \\
\hline \multirow[t]{7}{*}{ Jul11 } & 1 & Manisa & $\mathrm{C}$ & $\mathrm{c}$ & 12 & - & - & - & - \\
\hline & 2 & Manisa & $\mathrm{C}$ & $\mathrm{c}$ & 12 & - & - & - & - \\
\hline & 3 & Bursa & $\mathrm{D}$ & d & 15 & - & 11 & - & - \\
\hline & 4 & Ankara & $\mathrm{E}$ & d & 15 & - & - & 12 & 12 \\
\hline & 5 & Manisa & $\mathrm{C}$ & d & 12 & - & - & - & - \\
\hline & 6 & Bursa & $\mathrm{F}$ & $\mathrm{e}$ & 12 & - & - & - & - \\
\hline & 7 & Bursa & $\mathrm{F}$ & $\mathrm{e}$ & 12 & - & - & - & - \\
\hline \multirow[t]{8}{*}{ Aug11 } & 1 & Bursa & $\mathrm{F}$ & e & 15 & - & - & - & - \\
\hline & 2 & Manisa & $\mathrm{C}$ & $\mathrm{f}$ & 10 & - & - & - & - \\
\hline & 3 & Manisa & $\mathrm{C}$ & $\mathrm{f}$ & 10 & - & 18 & - & - \\
\hline & 4 & Bursa & G & g & 10 & - & 19 & - & - \\
\hline & 5 & Bursa & $\mathrm{H}$ & g & 10 & - & - & - & - \\
\hline & 6 & Bursa & I & $\mathrm{h}$ & 15 & - & - & - & - \\
\hline & 7 & Bursa & I & $\mathrm{h}$ & 15 & - & - & - & - \\
\hline & 8 & Bursa & I & $\mathrm{h}$ & 15 & - & - & - & - \\
\hline \multirow[t]{9}{*}{ Sept11 } & 1 & Bursa & I & $\mathrm{h}$ & 15 & - & - & - & - \\
\hline & 2 & Bursa & I & $\mathrm{h}$ & 15 & - & - & - & - \\
\hline & 3 & Bursa & I & $\mathrm{h}$ & 15 & - & - & - & - \\
\hline & 4 & Bursa & I & $\mathrm{h}$ & 15 & - & - & - & - \\
\hline & 5 & Bursa & I & $\mathrm{h}$ & 15 & - & - & - & - \\
\hline & 6 & Bursa & I & $\mathrm{h}$ & 15 & - & - & - & - \\
\hline & 7 & Bursa & I & $\mathrm{h}$ & 15 & - & - & - & - \\
\hline & 8 & Balıkesir & $\mathrm{J}$ & 1 & 15 & - & - & - & - \\
\hline & 9 & Balıkesir & $\mathrm{J}$ & 1 & 12 & - & - & - & - \\
\hline \multirow[t]{8}{*}{ Oct11 } & 1 & Balıkesir & $\mathrm{J}$ & 1 & 12 & - & - & - & - \\
\hline & 2 & Balıkesir & $\mathrm{J}$ & 1 & 12 & - & - & - & - \\
\hline & 3 & Balıkesir & $\mathrm{J}$ & 1 & 12 & - & - & - & - \\
\hline & 4 & Balıkesir & $\mathrm{K}$ & $\mathrm{j}$ & 12 & - & - & - & - \\
\hline & 5 & Balıkesir & $\mathrm{L}$ & $\mathrm{k}$ & 12 & - & - & - & - \\
\hline & 6 & Balıkesir & M & 1 & 15 & - & - & - & - \\
\hline & 7 & Balıkesir & M & 1 & 15 & - & 39 & - & - \\
\hline & 8 & Balıkesir & M & 1 & 15 & - & 40 & - & - \\
\hline \multirow[t]{7}{*}{ Nov11 } & 1 & Balıkesir & M & $\mathrm{m}$ & 15 & - & - & - & - \\
\hline & 2 & Bursa & $\mathrm{F}$ & $\mathrm{e}$ & 12 & - & - & - & - \\
\hline & 3 & Bursa & $\mathrm{F}$ & $\mathrm{e}$ & 12 & - & - & - & - \\
\hline & 4 & Bursa & $\mathrm{F}$ & $\mathrm{e}$ & 10 & - & - & - & - \\
\hline & 5 & Bursa & $\mathrm{F}$ & $\mathrm{e}$ & 15 & - & - & - & - \\
\hline & 6 & Manisa & $\mathrm{C}$ & $\mathrm{n}$ & 10 & - & - & - & - \\
\hline & 7 & Manisa & $\mathrm{C}$ & $\mathrm{n}$ & 12 & - & - & - & - \\
\hline
\end{tabular}


Table 1 resume.

Tablo 1 devam.

\begin{tabular}{|c|c|c|c|c|c|c|c|c|c|}
\hline \multicolumn{6}{|c|}{ Sampling strategy } & \multicolumn{4}{|c|}{ Results } \\
\hline \multirow{2}{*}{$\begin{array}{l}\text { Sampling } \\
\text { period }\end{array}$} & \multirow{2}{*}{$\begin{array}{c}\text { No of } \\
\text { samples }\end{array}$} & \multirow{2}{*}{ City } & \multirow{2}{*}{ Supplier } & \multirow{2}{*}{ Retailer } & \multirow{2}{*}{$\begin{array}{l}\text { No: eggs } \\
\text { sampled }\end{array}$} & \multicolumn{2}{|c|}{ Inner positive sample ID } & \multicolumn{2}{|c|}{ Shell positive sample ID } \\
\hline & & & & & & ISO & LCPCR & ISO & LCPCR \\
\hline \multirow[t]{7}{*}{ Dec11 } & 1 & Manisa & $\mathrm{C}$ & $\mathrm{n}$ & 12 & - & - & - & - \\
\hline & 2 & Manisa & $\mathrm{C}$ & $\mathrm{n}$ & 12 & - & - & - & - \\
\hline & 3 & Manisa & $\mathrm{C}$ & $\mathrm{n}$ & 12 & - & 50 & - & - \\
\hline & 4 & Manisa & $\mathrm{C}$ & $\mathrm{n}$ & 12 & - & & - & - \\
\hline & 5 & Ankara & $\mathrm{E}$ & $\mathrm{f}$ & 15 & - & 52 & - & - \\
\hline & 6 & Ankara & $\mathrm{E}$ & $\mathrm{f}$ & 15 & - & - & - & - \\
\hline & 7 & Ankara & $\mathrm{E}$ & $\mathrm{f}$ & 15 & - & - & - & 54 \\
\hline \multirow[t]{7}{*}{ Jan 12} & 1 & Ankara & $\mathrm{E}$ & $\mathrm{f}$ & 15 & - & - & - & - \\
\hline & 2 & Ankara & $\mathrm{E}$ & $\mathrm{f}$ & 15 & - & 56 & - & - \\
\hline & 3 & Bursa & $\mathrm{D}$ & $\mathrm{f}$ & 15 & - & - & - & 57 \\
\hline & 4 & Bursa & $\mathrm{D}$ & $\mathrm{f}$ & 15 & - & - & - & 58 \\
\hline & 5 & Bursa & D & $\mathrm{f}$ & 15 & - & - & - & - \\
\hline & 6 & Bursa & $\mathrm{D}$ & $\mathrm{f}$ & 15 & - & 60 & - & - \\
\hline & 7 & Bursa & $\mathrm{D}$ & f & 15 & - & 61 & - & - \\
\hline \multirow[t]{10}{*}{ Feb12 } & 1 & Ankara & $\mathrm{E}$ & $\mathrm{f}$ & 15 & - & - & - & 62 \\
\hline & 2 & Ankara & $\mathrm{E}$ & $\mathrm{f}$ & 15 & - & 63 & - & - \\
\hline & 3 & Ankara & $\mathrm{E}$ & $\mathrm{f}$ & 15 & - & 64 & - & - \\
\hline & 4 & Ankara & $\mathrm{E}$ & $\mathrm{f}$ & 15 & - & - & - & 65 \\
\hline & 5 & Ankara & $\mathrm{E}$ & $\mathrm{f}$ & 15 & - & 66 & - & - \\
\hline & 6 & Bursa & $\mathrm{D}$ & $\mathrm{f}$ & 15 & - & - & - & 67 \\
\hline & 7 & Bursa & $\mathrm{D}$ & $\mathrm{f}$ & 15 & - & 68 & - & - \\
\hline & 8 & Bursa & $\mathrm{D}$ & $\mathrm{f}$ & 15 & - & 69 & - & - \\
\hline & 9 & Bursa & $\mathrm{D}$ & $\mathrm{f}$ & 15 & - & 70 & - & - \\
\hline & 10 & Bursa & $\mathrm{D}$ & $\mathrm{f}$ & 15 & - & - & - & 71 \\
\hline \multirow[t]{12}{*}{ Mar12 } & 1 & Balıkesir & $\mathrm{N}$ & o & 12 & - & - & - & 72 \\
\hline & 2 & Balıkesir & $\mathrm{N}$ & o & 12 & 73 & - & - & - \\
\hline & 3 & Balıkesir & $\mathrm{N}$ & o & 12 & - & - & - & - \\
\hline & 4 & Balıkesir & $\mathrm{N}$ & o & 12 & - & 75 & - & - \\
\hline & 5 & Balıkesir & $\mathrm{N}$ & o & 12 & - & - & - & 76 \\
\hline & 6 & Balıkesir & $\mathrm{O}$ & $\mathrm{p}$ & 20 & - & 77 & - & - \\
\hline & 7 & Balıkesir & $\mathrm{O}$ & $\mathrm{p}$ & 20 & 78 & 78 & - & - \\
\hline & 8 & Balıkesir & $\mathrm{O}$ & $\mathrm{p}$ & 20 & - & 79 & - & - \\
\hline & 9 & Balıkesir & $\mathrm{O}$ & $q$ & 20 & 80 & 80 & - & - \\
\hline & 10 & Balıkesir & $\mathrm{O}$ & $q$ & 30 & - & - & - & 81 \\
\hline & 11 & Balıkesir & $\mathrm{O}$ & $q$ & 30 & - & - & 82 & 82 \\
\hline & 12 & Balıkesir & $\mathrm{O}$ & $q$ & 30 & 83 & 83 & - & - \\
\hline \multirow[t]{8}{*}{ Apr12 } & 1 & Balıkesir & $\mathrm{O}$ & $\mathrm{r}$ & 30 & - & 84 & - & - \\
\hline & 2 & Balıkesir & $\mathrm{O}$ & $\mathrm{r}$ & 30 & 85 & 85 & - & - \\
\hline & 3 & Balıkesir & $\mathrm{O}$ & $\mathrm{r}$ & 30 & 86 & - & - & - \\
\hline & 4 & Balıkesir & $\mathrm{O}$ & $\mathrm{r}$ & 30 & - & 87 & - & - \\
\hline & 5 & Balıkesir & $\mathrm{P}$ & $\mathrm{s}$ & 30 & - & - & 88 & 88 \\
\hline & 6 & Balıkesir & $\mathrm{P}$ & $\mathrm{s}$ & 30 & - & - & 89 & - \\
\hline & 7 & Balıkesir & $\mathrm{P}$ & $\mathrm{s}$ & 20 & - & - & - & 90 \\
\hline & 8 & Balıkesir & $\mathrm{P}$ & $\mathrm{s}$ & 20 & - & 91 & - & - \\
\hline
\end{tabular}


Table 1 resume.

Tablo 1 devam.

\begin{tabular}{|c|c|c|c|c|c|c|c|c|c|}
\hline \multicolumn{6}{|c|}{ Sampling strategy } & \multicolumn{4}{|c|}{ Results } \\
\hline \multirow{2}{*}{$\begin{array}{l}\text { Sampling } \\
\text { period }\end{array}$} & \multirow{2}{*}{$\begin{array}{c}\text { No of } \\
\text { samples }\end{array}$} & \multirow{2}{*}{ City } & \multirow{2}{*}{ Supplier } & \multirow{2}{*}{ Retailer } & \multirow{2}{*}{$\begin{array}{l}\text { No: eggs } \\
\text { sampled }\end{array}$} & \multicolumn{2}{|c|}{ Inner positive sample ID } & \multicolumn{2}{|c|}{ Shell positive sample ID } \\
\hline & & & & & & ISO & LCPCR & ISO & LCPCR \\
\hline \multirow[t]{10}{*}{ May12 } & 1 & Balıkesir & Q & $\mathrm{t}$ & 30 & 92 & - & 92 & - \\
\hline & 2 & Balıkesir & Q & $\mathrm{t}$ & 30 & - & - & 93 & 93 \\
\hline & 3 & Balıkesir & Q & $\mathrm{t}$ & 30 & 94 & - & - & - \\
\hline & 4 & Balıkesir & Q & $\mathrm{t}$ & 30 & 95 & - & - & - \\
\hline & 5 & Balıkesir & Q & $\mathrm{t}$ & 30 & 96 & 96 & - & - \\
\hline & 6 & Bursa & $\mathrm{D}$ & $\mathrm{f}$ & 15 & 97 & 97 & - & 97 \\
\hline & 7 & Bursa & $\mathrm{D}$ & $\mathrm{f}$ & 15 & - & 98 & - & - \\
\hline & 8 & Bursa & $\mathrm{D}$ & $\mathrm{f}$ & 15 & - & - & - & 99 \\
\hline & 9 & Bursa & $\mathrm{D}$ & $\mathrm{f}$ & 15 & - & 100 & - & - \\
\hline & 10 & Bursa & D & $\mathrm{f}$ & 15 & - & - & - & - \\
\hline Total & 101 & 5 & 16 & 20 & 1635 & 11 & 31 & 6 & 18 \\
\hline
\end{tabular}

Table 2. Relative accuracy, sensitivity and specificity results of LCPCR with reference to ISO method Tablo 2. LCPCR'ın ISO metoduna göre göreceli doğruluk, duyarlılık ve özgünlüğü

\begin{tabular}{|c|c|c|c|c|c|c|c|}
\hline \multirow{3}{*}{ Egg part (n) } & \multirow{2}{*}{\multicolumn{2}{|c|}{$\begin{array}{c}\text { Reference method } \\
\text { ISO }\end{array}$}} & \multirow{2}{*}{\multicolumn{2}{|c|}{$\begin{array}{c}\text { Alternative method } \\
\text { LCPCR }\end{array}$}} & \multirow{3}{*}{ Accuracy (\%) } & \multirow{3}{*}{$\begin{array}{l}\text { Sensitivity } \\
(\%)\end{array}$} & \multirow{3}{*}{$\begin{array}{c}\text { Specificity } \\
(\%)\end{array}$} \\
\hline & & & & & & & \\
\hline & Positive & Negative & False $_{\text {neg }}$ & False $_{\text {pos }}$ & & & \\
\hline Inner (101) & 6 & 65 & 5 & 25 & $70.3^{\mathrm{a}}$ & 72.2 & 54.5 \\
\hline Shell (101) & 4 & 81 & 2 & 14 & $84.2^{\mathrm{b}}$ & 85.3 & 66.7 \\
\hline Whole (101) & 10 & 45 & 7 & 39 & $54.5^{\mathrm{c}}$ & 53.6 & 58.8 \\
\hline
\end{tabular}

${ }^{\mathrm{a}-\mathrm{c}}$ Kappa index values $0.15,0.27$, and 0.27 , respectively.

${ }^{\mathrm{a}-\mathrm{c}}$ Kappa indeks değerleri sirasıyla $0.15,0.27$ ve 0.27 'dir.

${ }^{\text {a }}$ There was almost no agreement between ISO and PCR.

${ }^{\text {a }}$ ISO ve PCR arasında hemen hemen hiçbir uyum bulunmamaktadır.

${ }^{\mathrm{b}}$ Fair agreement between methods

${ }^{\mathrm{b}}$ Metotlar arasında kayda değer bir uyum bulunmaktadır.

${ }^{\mathrm{c}}$ Slight agreement between methods

${ }^{\mathrm{c}}$ Metotlar arasında zayıf bir uyum bulunmaktadır.

Serotyping results of the 16 isolates of inner and shell parts revealed that all were SE.

When LCPCR was compared to ISO as the reference method, 5 and 2 false-negative samples were detected in inner and shell parts of the egg samples. The relative accuracy rates were $70.3 \%, 84.2 \%$ for inner egg and shell egg samples, respectively (Table 2), indicating only a fair agreement between ISO and LCPCR on shell samples only. The relative sensitivity and specificity of shell part LCPCRs were comparably higher than those of inner and whole egg samples. The number of false positives in LCPCR resulted in lower agreement between methods, as well as lowering the relative specificity and sensitivity of the test (Table 2).

\section{Discussion and Conclusion}

The aim of this study was to determine the presence of Salmonella in retail grade A eggs by using both ISO and LCPCR to complement ISO. Our ISO results indicated that $10.9 \%$ of inner and $5.9 \%$ of shell (overall $15.8 \%$ ) of the retail eggs harbored Salmonella. Our inner part rate is higher than previous studies reported from different parts of the world $(4,8,12,19,28)$, which have found this rate as $0-7.4 \%$ in retail eggs, contrary to a study by Betancor et al. (2), indicating a considerably higher rate of 35\% Salmonella from Uruguay. Similarly, there are several previous studies with lower Salmonella shell rates as $0-5.3 \%(4,12,24)$ than ours, two studies with higher rates as $15.8 \%$ (21) and $21 \%$ (8), and one study by Suresh et al. (28) indicating a slightly higher rate as $6.1 \%$ than ours. The differences between the rates we detected with the previously conducted studies can be linked to factors such as: (1) layers: housing, management - production practices, genetic background, Salmonella control and vaccination programs used; (2) applied/restricted egg processing practices: washing, sanitizing, oiling, drying, storage temperature conditions, cleaning; (3) region and climate: geographical area, 
season; (3) sample: methods used in sampling, method of analysis, sample number, duration of sampling. As indicated by Jones et al. (18), comparison of egg microbiology data on Salmonella around the world stays inconclusive and is difficult to compare due to above and related reasons.

The Salmonella isolation rate from inner parts of the eggs is higher than the shell rate, contrary to the similar previous studies, which have lower or $0 \%$ inner rate compared to higher shell rates $(4,8,12,28)$. This difference could be the result of many contributing factors in those studies and our study, and cannot be extrapolated further.

Our serotyping results revealed that all Salmonella isolates belonged to the serovar Enteritidis, similar to the findings of Suresh et al. (28), Adesiyun et al. (1) and Betancor et al. (2), and in contrast to Musgrove et al. (21) and Lee et al. (19).

In this study, we used LCPCR to complement ISO in detecting Salmonella from naturally contaminated egg samples, and determined relatively high Salmonella detection rates (Overall 46.5\%, inner 30.7\%, shell $17.8 \%$ ). The higher positivity in LCPCR had previously been observed in some 'poultry meat-related' LCPCR studies by Bohaychuk et al. (3) and Eyigor et al. (10), and was related factors such as high numbers of nonculturable/dead Salmonella cells in the sample, insufficient recovery of sub-lethally injured cells, despite specific enrichment in the culture-based method $(3,9)$. However, correlating this high LCPCR rate in our egg samples only to the factors mentioned above seemed inconclusive. Therefore, we sought for other reasons for this result, and went through the available product specifications and applicability statement in the kit insert. The sequencespecific Foodproof Salmonella Master Mix Kit designed to amplify 'a highly conserved gene' found in all subgroups of Salmonella, was notified as tested for inclusivity with more than 700 strains of Salmonella comprising all subspecies, and for exclusivity using 60 species of closely related organisms or organisms occurring in the same habitat. This was satisfactory from the point of specificity, whereas the sensitivity of the kit was slightly high, indicated as $10^{4} \mathrm{cfu} / \mathrm{ml}$ detection limit in enrichment cultures. This made us think that despite $\mathrm{PE}$ and $\mathrm{PrE}$, if/when initial sub-lethally injured/low numbers of cells were present in the eggs, these cells somehow might not have reached the levels in enrichments to compete with non-Salmonella flora disturbing selective plate readings, and eventually leading to false negativity in culture. Also, performance of the Salmonella culture method (number of positive isolations) was recently reported to depend on other factors, such as to the motility of the Salmonella isolate $(26,27)$, to the choice/appropriateness, and incubation period in selective medium. These may be some of the further contributing factors affecting our relatively lower culture rate, which would still require specific investigations.

The milieu (here egg content/shell) in which the bacterium (here Salmonella) resides prior isolation/ detection is another equally important issue in defining the appropriateness of the assay kit developed for the detection of a specific pathogen. Therefore, we also checked if this kit was applicable for detecting Salmonella from 'naturally contaminated eggs'. Indication of the following note in the applicability statement of the kit insert as: 'the Foodproof Salmonella Detection Kit has an intended use for the rapid detection of Salmonella DNA isolated from enrichment cultures prepared by valid methods, such as NordVal with the ISO 6579 method for five food groups including eggs' reassured us that we used a proper kit for our purposes.

In this study, Salmonella was detected in $10 \mathrm{egg}$ (inner + shell) samples by both methods, in 6 samples only by ISO compared to 37 positives only by LCPCR (Table 1). In contrast to our high LCPCR positivity, Soria et al. (25) reported that their PCR results were not as good as the culture method results for some Salmonella strains, where they compared two culture methods and a PCR assay to detect Salmonella in artificially contaminated egg content. They concluded that further studies were required to improve PCR methods' performance parameters and limit of detection compared to culture for the test to find use in poultry and food industry.

Although not entirely relevant, due to incoherence with their scope, we evaluated our LCPCR result with some recently performed study(ies), of none tested their PCR to detect Salmonella in potentially naturally contaminated retail eggs. One of these studies was a realtime PCR developed by Chen et al. (5) was used for detecting SE in artificially contaminated foods, including liquid eggs. In another survey study by Gole et al. (12) PCR was utilized to detect the presence of several virulence genes in Salmonella they isolated from eggs of commercial laying flocks. A recent study by Lee et al. (19) applied real-time PCR in confirming presumptive Salmonella isolates after standard metabolic and biochemical tests. All these studies once more indicate PCR's indispensible advantages in detecting Salmonella and SE in complementing culture methods.

To conclude, grade A eggs produced in our country can still pose a risk factor for Salmonella in its separate consumption in different forms, and as crosscontamination to other foods in household and catering kitchens. This public health problem as foodborne salmonellosis and outbreaks require fundamental and strict approaches in biosecurity applications in layer farms, with routine Salmonella monitoring by reliable detection methods to reduce the presence in retail eggs. 


\section{Acknowledgements}

This work was funded by the Uludag University Scientific Research Unit Grant, Project No: 2010/10.

\section{References}

1. Adesiyun A, Offiah N, Seepersadsingh N, Rodrigo S, Lashley V, Musai L (2007): Antimicrobial resistance of Salmonella spp. and Escherichia coli isolated from table eggs. Food Control, 18, 306-311.

2. Betancor L, Pereira M, Martinez A, Giossa G, M. Fookes, K. Flores, P. Barrios, V. Repiso, R. Vignoli, N. Cordeiro, G. Algorta, N. Thomson, D. Maskell, F. Schelotto, JA Chabalgoity (2010): Prevalence of Salmonella enterica in poultry and eggs in Uruguay during an epidemic due to Salmonella enterica serovar Enteritidis. J Clin Microbiol 48, 2413-2423.

3. Bohaychuk VM, Gensler GE, McFall ME, King RK, Renter DG (2007): A real time PCR assay for the detection of Salmonella in a wide variety of food and foodanimal matrices. J Food Prot, 70, 1080-1087.

4. Cakiroglu HS, Gumussoy KS (2005): Ankara garnizonunda tüketime sunulan tavuk yumurtalarınin Salmonella spp. yönünden analizi. Sag Bil Derg, 14, 158-162.

5. Chen J, Zhang L, Paoli GC, Shi C, Tu S, Shi X: (2010) A real-time PCR method for the detection of Salmonella enterica from food using a target sequence identified by comparative genomic analysis. Int J Food Microbiol, 137, 16-174.

6. Cogan TA, Humphrey TJ (2003): The rise and fall of Salmonella Enteritidis in the UK. J Appl Microbiol, 94 (Suppl), 114-119.

7. EFSA (2007): Report of the task force on zoonoses data collection on the analysis of the baseline survey on the prevalence of Salmonella in broiler flocks of Gallus gallus, in the EU, 2005-2006. Part A: Salmonella prevalence estimates. EFSA J, 1-85.

8. Erkan ME, Vural A, Güran HŞ (2008): Diyarbakır ilinde satışa sunulan köy ve market yumurtalarının hijyenik kalitesi üzerine bir araștırma. J Dicle Univ Vet Fac, 1, 11-16.

9. Eyigor A, Carli KT, Unal CB (2002): Implementation of real-time PCR to tetrathionate broth enrichment step of Salmonella detection in poultry. Lett Appl Microbiol, 34, 37-41.

10. Eyigor A, Temelli S, Carli KT (2010): Evaluation of ISO 6579 and FDA-BAM methods to complement real-time polymerase chain reaction for the detection of Salmonella in naturally contaminated poultry meat and red meat. Foodborne Pathog Dis, 7, 921-927.

11. Food and Drug Administration Bacteriological Analytical Manual (2011): FDA Chapter 5: Salmonella. Ed. Andrews WH, Jacobson A, Hammack T. Available at http://www.fda.gov/Food/FoodScienceResearch/Laborator yMethods/ucm070149.htm (accessed September 2013).

12. Gole VC, Chousalkar KK, Roberts JR (2013): Survey of Enterobacteriaceae contamination of table eggs collected from layer flocks in Australia. Int J Food Microbiol, 164, 161-165.

13. Grimont PAD, Weill F (2007): Antigenic formulae of the Salmonella serovars: White-Kauffmann-Le Minor Scheme, 9th edition. WHO Collaborating Centre for Reference and Research on Salmonella. Available at http://www.pasteur.fr/ip/portal/action/WebdriveActionEve nt/oid/01 s-000036-089 (accessed September 2013).

14. Guibourdenche M, Roggent P, Mikoleit M, Fields PI, Bockemühl J, Grimont PA, Weill FX (2010): Supplement 2003-2007 (No. 47) to the White-KauffmannLe Minor scheme. Res Microbiol, 161, 26-29.

15. International Organization for Standardization (2002): Microbiology of food and animal feeding stuffs. Horizontal method for the detection of Salmonella spp. ISO 6579:2002 (E).

16. International Organization for Standardization (2003a): Microbiology of food and animal feeding stuffsPreparation of test samples, initial suspension and decimal dilutions for microbiological examination. Part 4: Specific rules for the preparation of products other than milk and milk products, meat and meat products, and fish and fishery products. ISO 6887-4:2003/Cor.1: 2004 (E).

17. International Organization for Standardization (2003b): Microbiology of Food and Animal Feeding StuffsProtocol for the Validation of Alternative Methods. ISO 16140:2003 (E).

18. Jones DR, Anderson KE, Musgrove MT (2011): Comparison of environmental and egg microbiology associated with conventional and free-range laying hen management. Poultry Sci, 90, 2063-2068.

19. Lee SK, Chon JW, Song KY, Hyeon JY, Moon JS, Seo KH (2013): Prevalence, characterization, and antimicrobial susceptibility of Salmonella Gallinarum isolated from eggs produced in conventional or organic farms in South Korea. Poultry Sci, 92, 2789-2797.

20. Malorny B, Löfström C, Wagner M, Kramer N, Hoorfar J (2008): Enumeration of Salmonella bacteria in food and feed samples by real-time PCR for quantitative microbial risk assessment. Appl Environ Microbiol, 74, 1299-1304.

21. Musgrove MT, Jones DR, Northcutt JK, Harrison MA, Cox NA, Ingram KD, Hinton AJ Jr (2005): Recovery of Salmonella from commercial shell eggs by shell rinse and shell crush methodologies. Poultry Sci, 84, 1955-1958.

22. Pangloli P, Dje Y, Ahmed O, Doane CA, Oliver SP, Draughon FA (2008): Seasonal incidence and molecular characterization of Salmonella from dairy cows, calves, and farm environment. Foodborne Pathog Dis, 5, 87-96.

23. Rebolledo J, Garvey P, Ryan A, O'Donnell J, Cormican M, Jackson S, Cloak F, Cullen L, Swaan CM, Schimmer B, Appels RW, Nygard K, Finley R, Sreenivasan N, Lenglet A, Gossner C, McKeown P (2013): International outbreak investigation of Salmonella Heidelberg associated with in-flight catering. Epidemiol Infect, doi:10.1017/S0950268813001714.

24. Sasaki Y, Tsujiyama Y, Asai T, Noda Y, Katayama S, Yamada Y (2011): Salmonella prevalence in commercial raw shell eggs in Japan: A survey. Epidemiol Infect, 139, 1060-1064.

25. Soria MA, Soria MC, Bueno DJ (2012a): A comparative study of culture methods and polymerase chain reaction for Salmonella detection in egg content. Poultry Sci, 91, 2668-2676. 
26. Soria MC, Soria MA, Bueno DJ, Colazo JL (2011): A comparative study of culture methods and polymerase chain reaction assay for Salmonella detection in poultry feed. Poultry Sci, 90, 2606-2618.

27. Soria, MC, Soria MA, Bueno DJ (2012b): Comparison of 2 culture methods and PCR assays for Salmonella detection in poultry feces. Poultry Sci, 91, 616-626.

28. Suresh T, Hatha AAM, Sreenivasan D, Sangeetha N, Lashmanaperumalsamy $\mathbf{P}$ (2006): Prevalence and antimicrobial resistance of Salmonella enteritidis and other salmonellas in the eggs and egg-storing trays from retails markets of Coimbatore, South India. Food Microbiol, 23, 294-299.
29. Wilson IG (1997): Inhibition and facilitation of nucleic acid amplification. Appl Environ Microb, 63, 3741-3751.

Geliş tarihi: 17.02.2014/ Kabul tarihi: 14.07.2014

Address for correspondence:

Prof. Dr. Ayşegül Eyigör

Uludağ University,

Faculty of Veterinary Medicine,

Department of Food Hygiene and Technology, 16059, Görükle Campus, Bursa, Turkey

e-mail:aeyigor@uludag.edu.tr 